\title{
Evaluation of Anti-obesity Effect of Fattolin, a Polyherbal Formulation in Progesterone Induced Obesity in Mice
}

\author{
Dilpesh Jain', Preeti Bavage', Akansha Sable ${ }^{1}$, Mitali Gokhale1 \\ 1Department of Pharmacology, Sinhgad College of Pharmacy, Pune-411041, INDIA.
}

\begin{abstract}
Progesterone imbalance modulates lipids and fats metabolism leading to obesity. Polyherbal formulation, Fattolin is currently being used in the treatment of obesity but not reported scientifically. Thus the present study investigates the anti-obesity effect of Fattolin in progesterone induced obesity model. Female Swiss albino mice were divided in four groups $(n=6)$ and treated for 28 days, Group I received $2 \%$ gum acacia $(10 \mathrm{ml} / \mathrm{kg})$; Group II, III and IV received progesterone $(10 \mathrm{mg} / \mathrm{kg}$ ) subcutaneously and Group III and IV further received Fattolin orally at dose of $200 \mathrm{mg} / \mathrm{kg}$ and $400 \mathrm{mg} / \mathrm{kg}$ respectively. Increased food intake, body weight, liver weight, relative liver weight and, altered exploratory behaviour and biochemical estimations as well as histopathological changeswereobserved in non-treated progesterone control mice. Fattolin treatment 1200 and $400 \mathrm{mg} / \mathrm{kg}$ ) significantly decreased food intake, body weight and liver weight. A significant increase in number of ambulation and rearing and decrease in grooming was also observed. Moreover it significantlydecreased levels of blood glucose, triglycerides, total cholesterol, LDL, VLDL and liver enzymes; however more significant difference was observed with Fattolin $400 \mathrm{mg} / \mathrm{kg}$ treatment. Structural abnormality of hepatocytes like mild congestion and focal necrosis induced by progesterone administration was markedly improved with Fattolin treatment at both doses. Thus it can be concluded that, a polyherbal formulation, Fattolin possesses an anti-obesity activity.
\end{abstract}

Key words: Fattolin, Progesterone, Obesity, Total cholesterol, Body weight.

\section{INTRODUCTION}

The current scenario suggests a significant hike in the prevalence of lifestyle associated disorders across the globe. A series of disorders can be classified under this term including obesity. Obesity reduces life expectancy and poses a serious negative effect on the health of an individual, owing to fat accumulation in the body. ${ }^{1}$ Globally, 400 million people are obese with Body Mass Index (BMI) above $30 .^{2}$ Apart from imbalance between the energy consumption and its utilization, hormones play an important role in the development of obesity. The fluctuating levels of various hormones like leptin, insulin, sex hormones and growth hormone are majorly seen to influence the appetite, body fat distribution, metabolism and storage., ${ }^{3,4}$ The female population has higher prevalence for the development of obesity owing to the changes in the levels of sex hormones. ${ }^{5}$ Ovarian sex steroids like oestrogen and progesterone through action on their respective receptors possess a significant effect on substrate metabolism.

Progesterone is an endogenous hormone regulates embryogenesis, pregnancy, lactation and menstrual cycle. ${ }^{7}$ It also acts as a potent neurosteroid and exerts neuroprotective and neurogenic action as well as regulates the release of various neurotransmitters. ${ }^{8}$
Submission Date: 11-01-2016 Revision Date : :29-02-2016 Accepted Date : :15-04-2016

DOI: 10.5530/ijper.50.3.11 Correspondence: Prof. Dilpesh Jain AssistantProfessor, Department of Pharmacology, Sinhgad College of Pharmacy, S.N0.44/1, OffSinhgad Road, Vadgaon(Bk.), Pune-411041, INDIA.

MobileNo:+919423614296 E-mail:dilpeshjain@yahoo. com

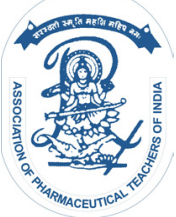

www.ijper.org 
It is a major component used either alone or in combination with oestrogen in Hormone replacement therapy (HRT) and oral contraceptives. Hormone therapy schedules (sequential or combined- continuous), recommends use of progesterone over a longer duration. Oral contraceptives containing progesterone are recommended when oestrogen is contraindicated in women. ${ }^{9}$ These are highly effective with approximately $0.3 \%$ failure rate. ${ }^{10}$ Progesterone induces hyperphagia and thereby increased fat deposition and contributes to weight gain by interfering with carbohydrate and lipid metabolism. ${ }^{11,12}$ Progesterone induced obesity is one of the well-established model for screening of anti-obesity agents.

Although numerous centrally and peripherally acting agents are available for effective management of obesity, their use is limited owing to the associated side effects like dry mouth, constipation, insomnia and palpitations, dizziness, paraesthesia, potential risk of psychiatric disorders, myocardial infarction and many more. ${ }^{13,14}$ However, herbal formulations are gaining major limelight due to synergistic action and lesser side effects as compared to synthetic moieties. ${ }^{15}$ Fattolin is a polyherbal formulation recommended for the treatment of obesity. It is composed of Shunthi (Zinziber officinale), Marich (Piper nigrum), Pippali (Piper longum), Chitrak (Plumbago zeylanica), Vidanga (Embeliaribes), Gokshur (Tribulus terrrestris), Triphala and Guggul (Commiphora wightii). These phytoconstituents have been reported for various actions like carminative, hypolipidemic and thermo genesis. ${ }^{16-19}$ Safety profile of this formulation is already established and is considered safe for oral administration. ${ }^{20}$ Thus, the present study was undertaken to investigate the anti-obesity effect of Fattolin in progesterone induced obesity in laboratory mice.

\section{MATERIALS AND METHODS}

\section{Drug and Chemicals}

Fattolin (Sharangdhar Pharmaceuticals, Pune, India) and Progesterone (Proluton Depot $250 \mathrm{mg} / \mathrm{ml}$ (hydroxyprogesterone) was purchased from local market of Pune. Commercial diagnostic kits were procured from Biolab (Mumbai, India), Crest systems (Goa, India) and Robonik (Navi Mumbai, India). All other reagents and chemicals used were purchased from local suppliers of Pune, India.

\section{Experimental animals}

Female Swiss albino mice (25-30 g) were procured from National Institute of Biosciences, Pune. The experimental animals were maintained under standard laboratory conditions at temperature of $23 \pm 2^{\circ} \mathrm{C}$ with relative humidity $55 \pm 10 \% .12 \mathrm{~h}$ light and $12 \mathrm{~h}$ dark cycle was maintained throughout the experiment. The animals were fed with standard pellet diet and water ad libitum. All the experimental procedures and protocols were approved by the Institutional Animal Ethical Committee.

\section{Experimental design}

Twenty four female Swiss albino mice were randomly divided into four groups $(n=6)$ and were treated daily for 28 days. Group I received $2 \%$ gum acacia $(10 \mathrm{ml} / \mathrm{kg}$, p.o.). Group II received progesterone $(10 \mathrm{mg} / \mathrm{kg})$ subcutaneously. Group III and IV received Fattolin orally at dose of $200 \mathrm{mg} / \mathrm{kg}$ and $400 \mathrm{mg} / \mathrm{kg}, 30 \mathrm{~min}$ before progesterone administration. Progesterone was dissolved in arachis oiland administered subcutaneously in the dorsal neck region. Powder of Fattolin tablet was suspended in $2 \%$ gum acacia. ${ }^{21}$

\section{Food intake}

The effect of Fattolin on food intake was recorded on day 1, 7, 14, 21 and 28. The mice were deprived of food $1 \mathrm{hr}$ prior to experimentation. On these days $10 \mathrm{~g}$ of sweetened corn was presented to groups of mice in glass petri dishes and food intake was recorded at 0.5 , 1 and $2 \mathrm{hr}$ time intervals. The result was recorded as average of all the weeks at respective time intervals and amount of food consumed/20 g body weight was calculated. ${ }^{22}$

\section{Body weight, organ weight and relative organ weight}

The body weight of mice was recorded on day 1and day 29 using an electronic balance and the \% change in their body weight was calculated. At the end of the experiment mice were sacrificed and liver was isolated, weighed and relative liver weight was calculated.

Relative liver weight $=($ liver weight $/$ Body weight $) \times 100$

\section{Exploratory behaviour}

On $28^{\text {th }}$ day, post 30 min of drug administration ambulation, grooming and rearing was noted by means of open field test. The animals were kept under laboratory conditions for one hour prior to the test. Open field test was performed by placing the mice in the centre and ambulatory activity (squares crossed by horizontal movement) as well as frequency of rearing

(Standing up vertically) and grooming (face washing and repetitive licks directed to body) wasrecordedfor five minutes using a camcorder for noting the exact reading and storage of data. ${ }^{23}$

\section{Biochemical estimations}

On $29^{\text {th }}$ day blood was withdrawn by retro-orbital puncture from over-night fasted mice. Blood was centrifuged at 
$3000 \mathrm{rpm}$ for $15 \mathrm{~min}$ and serum was separated. Biochemical parameters like blood glucose ${ }^{24}$ total cholesterol (TC), ${ }^{25}$ high density lipoprotein (HDL) (25), triglyceride $(\mathrm{TG}){ }^{26}$ serum glutamate oxaloacetate transaminase (SGOT), and serum glutamate pyruvate transaminase $(\mathrm{SGPT})^{27}$ were estimated using commercial diagnostic kits by Chem star Biochemical Semi Auto analyser. Where as the low density lipoprotein (LDL) and very low density lipoprotein (VLDL)levels were calculated according to Friedwald's formula. ${ }^{28}$

LDL in $\mathrm{mg} \%=$ Total cholesterol - HDL-C Triglycerides $/ 5$

VLDL in $\mathrm{mg} \%=$ Triglycerides $/ 5$

\section{Histopathological examinations}

At the end of experiment mice were sacrificed by cervical dislocation, liver was isolated and stored in 10\% formalin solution. The sections of liver were stained with haematoxylin and eosin and observed under light microscope (100x).

\section{STATISTICAL ANALYSIS}

The results were expressed as mean \pm SEM. The data was analysed by one way analysis of variance (ANOVA) followed by Tukey's test and two way analysis of variance (ANOVA) followed by Bonferroni test. Whereas $P<0.05$ was considered as minimum level of significance.

\section{RESULTS}

\section{Food intake}

As shown in Figure 1. Subcutaneous administration of progesterone $(10 \mathrm{mg} / \mathrm{kg})$ in mice for 28 days significantly increased food intake post $2 \mathrm{~h}$ when compared with normal control mice $(\mathrm{P}<0.001)$. Whereas, oral administration of Fattolin (200 and $400 \mathrm{mg} / \mathrm{kg}$ ) along with progesterone injection produced significant decrease in food intake in mice post $0.5 \mathrm{hr}(\mathrm{P}<0.05$ and $\mathrm{P}<0.001), 1 \mathrm{hr}(\mathrm{P}<0.01$ and $\mathrm{P}<0.001), 2 \mathrm{hrs}(\mathrm{P}<0.05$ and $\mathrm{P}<0.001)$ when compared with progesterone control mice. Further a significant difference was also noted in Fattolin $400 \mathrm{mg} / \mathrm{kg}$ treated mice as compared to $200 \mathrm{mg} / \mathrm{kg}$.

\section{Body weight, liver weight and relative liver weight}

A significant increase in the body weight of non-treated progesterone control mice was observed when compared with normal control mice $(\mathrm{P}<0.001)$. Fattolin treatment at doses of 200 and $400 \mathrm{mg} / \mathrm{kg}$ body weight in progesterone injected mice significantlyrestored the body weight as compared to the non-treated progesterone control mice $(\mathrm{P}<0.001$ and $\mathrm{P}<0.001$; respectively).
Further a significant difference in the body weight was also observed in the Fattolin $400 \mathrm{mg} / \mathrm{kg}$ treated mice as compared to Fattolin $200 \mathrm{mg} / \mathrm{kg}$ treatment $(\mathrm{P}<0.05)$. Moreover significantly increased liver weight due to progesterone injection was also restored with the oral administration of Fattolin at dose levels of 200 and 400 $\mathrm{mg} / \mathrm{kg}$ body weight as compared to non-treated progesterone control mice $(\mathrm{P}<0.05$ and $\mathrm{P}<0.01$; respectively). However administration of progesterone or Fattolin could not produce significant change in the relative liver weight (Table 1 and Figure 2).

\section{Exploratory behaviour}

As shown in Table 2, A significant decrease in the number of ambulation and rearing $(\mathrm{P}<0.001$ and $\mathrm{P}<0.001$; respectively) as well as increase grooming $(\mathrm{P}<0.01)$ was observed in non-treated progesterone control as compared to control mice. Whereas mice treated with Fattolin 200 and $400 \mathrm{mg} / \mathrm{kg}$ orally for 28 days along with progesterone significantly increased the number of ambulation $(\mathrm{P}<0.001$ and $\mathrm{P}<0.01$; respectively), rearing $(\mathrm{P}<0.05$ and $\mathrm{P}<0.05$; respectively) and decreased grooming $(\mathrm{P}<0.01)$ as compared to progesterone control mice. However no significant change was observed between Fattolin 400 and $200 \mathrm{mg} / \mathrm{kg}$ treatment.

\section{Biochemical estimations}

As shown in Table 3, daily subcutaneous administration of progesterone for 28 days significantly increased the levels of blood glucose $(\mathrm{P}<0.001)$, total cholesterol $(\mathrm{P}<0.001)$, triglyceride $(\mathrm{P}<0.001)$, and LDL $(\mathrm{P}<0.001)$ and VLDL $(\mathrm{P}<0.001)$ as well as decreased HDL $(\mathrm{P}<0.001)$ as compared to control mice. However the mice treated with Fattolin at a dose level of 200 and $400 \mathrm{mg} / \mathrm{kg}$ body weight significantly decrease the elevated levels of blood glucose $(\mathrm{P}<0.001$ and $\mathrm{P}<0.001$; respectively), total cholesterol $(\mathrm{P}<0.05$ and $\mathrm{P}<0.001$; respectively), triglyceride $(\mathrm{P}<0.05$ and $\mathrm{P}<0.001$; respectively), and LDL $(\mathrm{P}<0.01$ and $\mathrm{P}<0.001$; respectively) and VLDL $(\mathrm{P}<0.05$ and $\mathrm{P}<0.001$; respectively) as well as increased HDL $(\mathrm{P}<0.05$ and $\mathrm{P}<0.01$; respectively) compared to the progesterone treated mice. Moreover, in comparison with Fattolin $200 \mathrm{mg} / \mathrm{kg}$ treatment, Fattolin $400 \mathrm{mg} / \mathrm{kg}$ produced a significantlydecreaseblood glucose $(\mathrm{P}<0.05)$, total cholesterol $(\mathrm{P}<0.01)$, triglyceride $(\mathrm{P}<0.05)$, LDL $(\mathrm{P}<0.01)$ and VLDL $(\mathrm{P}<0.05)$ levels whereas, no significant effect was observed in HDL.

An elevated levels of SGOT and SGPT (P<0.001 and $\mathrm{P}<0.001$ respectively) in the non-treated progesterone control mice were significantly decreased with 28 days of Fattolin $200 \mathrm{mg} / \mathrm{kg}$ and $400 \mathrm{mg} / \mathrm{kg}$ treatment, 


\begin{tabular}{|c|c|c|c|}
\hline \multicolumn{3}{|c|}{ Table 1: Effect of four weeks treatment of Fattolin on body weight (\%), } \\
liver weight and relative liver weight \\
\hline Treatment (mg/kg) & $\begin{array}{c}\text { Body weight } \\
(\%)\end{array}$ & $\begin{array}{c}\text { Liver weight } \\
(\mathbf{g})\end{array}$ & Absolute liver weight (\%) \\
\hline Control & $15.13 \pm 1.23$ & $1.39 \pm 0.02$ & $9.18 \pm 0.01$ \\
\hline Progesterone (10) & $40.59 \pm 1.05^{c}$ & $2.34 \pm 0.11^{c}$ & $5.76 \pm 0.10$ \\
\hline Fattolin (200) & $23.77 \pm 1.50^{\circledR}$ & $1.89 \pm 0.08^{*}$ & $7.95 \pm 0.05$ \\
\hline Fattolin (400) & $17.01 \pm 2.02^{\circledR} \$$ & $1.79 \pm 0.10^{\#}$ & $10.52 \pm 0.04$ \\
\hline
\end{tabular}

$\mathrm{n}=6$, One way ANOVA followed by Tukey's test.

${ }^{\mathrm{P}} \mathrm{P}<0.001$ VsControl. ${ }^{*} \mathrm{P}<0.05,{ }^{\#} \mathrm{P}<0.01$, ${ }^{\circledR} \mathrm{P}<0.001$ Vs Progesterone. ${ }^{\mathrm{s}} \mathrm{P}<0.05$ VsFattolin (200).

\section{Table 2: Effect of four weeks treatment of Fattolin on exploratory behaviour}

\begin{tabular}{|c|c|c|c|}
\hline Treatment (mg/kg) & Ambulation & Rearing & Grooming \\
\hline Control & $83.33 \pm 1.49$ & $10.50 \pm 1.17$ & $2.0 \pm 0.36$ \\
\hline Progesterone (10) & $59.50 \pm 3.46^{\mathrm{c}}$ & $5.66 \pm 0.33^{\mathrm{c}}$ & $4.33 \pm 0.49^{\mathrm{b}}$ \\
\hline Fattolin (200) & $73.83 \pm 1.10^{\circledR}$ & $8.66 \pm 0.55^{*}$ & $3.16 \pm 0.30$ \\
\hline Fattolin (400) & $69.67 \pm 0.76^{\#}$ & $9.16 \pm 0.65^{*}$ & $2.0 \pm 0.25^{\#}$ \\
\hline
\end{tabular}

$\mathrm{n}=6$, One way ANOVA followed by Tukey's test.

${ }^{\mathrm{b} P}<0.01,{ }^{\mathrm{C}} \mathrm{P}<0.001 \mathrm{Vs}$ Control; ${ }^{*} \mathrm{P}<0.05,{ }^{\#} \mathrm{P}<0.01,{ }^{\circledR} \mathrm{P}<0.001$ Vs Progesterone.

\begin{tabular}{|c|c|c|c|c|}
\hline & Control & Progesterone (10) & $\begin{array}{c}\text { Fattolin } \\
(200)\end{array}$ & $\begin{array}{c}\text { Fattolin } \\
(400)\end{array}$ \\
\hline Blood glucose (mg/dl) & $72.33 \pm 2.04$ & $123.00 \pm 1.89^{c}$ & $104.20 \pm 3.0^{@}$ & $94.67 \pm 2.47 @ \$$ \\
\hline $\mathrm{TC}(\mathrm{mg} / \mathrm{dl})$ & $90.33 \pm 2.59$ & $129.7 \pm 2.90^{c}$ & $117.0 \pm 2.19^{*}$ & $101.3 \pm 2.98 @ 8$ \\
\hline $\mathrm{TG}(\mathrm{mg} / \mathrm{dl})$ & $98.50 \pm 3.78$ & $133.7 \pm 2.26^{c}$ & $123.3 \pm 1.67^{*}$ & $113.2 \pm 1.26 @ \$$ \\
\hline $\mathrm{HDL}(\mathrm{mg} / \mathrm{dl})$ & $25.17 \pm 0.98$ & $15.02 \pm 1.70^{c}$ & $20.17 \pm 0.94^{*}$ & $22.67 \pm 0.98^{\#}$ \\
\hline LDL (mg/dl) & $45.47 \pm 2.52$ & $87.90 \pm 3.39^{c}$ & $72.17 \pm 2.31^{\#}$ & $56.03 \pm 2.59 @ 8$ \\
\hline $\operatorname{VLDL}(\mathrm{mg} / \mathrm{dl})$ & $19.70 \pm 0.74$ & $26.73 \pm 0.45^{c}$ & $24.67 \pm 0.33^{*}$ & $22.63 \pm 0.25^{@ \$}$ \\
\hline SGOT (IU/L) & $136.8 \pm 1.01$ & $152.5 \pm 1.33^{c}$ & $141.2 \pm 1.13^{@}$ & $139.2 \pm 0.74 @$ \\
\hline SGPT (IU/L) & $66.33 \pm 1.28$ & $82.50 \pm 1.64^{c}$ & $76.00 \pm 1.00^{\#}$ & $69.33 \pm 0.81 @ 8$ \\
\hline
\end{tabular}

$\mathrm{n}=6$, One way ANOVA followed by Tukey's test

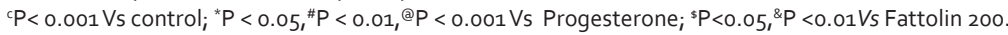

TC- Total cholesterol, TG-Triglyceride, HDL- High density lipoprotein, LDL- Low density lipoprotein, VLDL- Very low density lipoprotein, SGOT-Serum glutamate oxaloacetate transaminase, SGPT-Serum glutamate pyruvate transaminase.

SGOT $(\mathrm{P}<0.001$ and $\mathrm{P}<0.001$; respectively) and SGPT $(\mathrm{P}<0.01$ and $\mathrm{P}<0.001$ respectively) as compared to nontreated progesterone control mice.

\section{Histopathological examination}

As shown in Figure 2, stained sections of liver of the control mice revealed no structural abnormalities. Mild congestion and focal necrosis was observed in hepatocyte of non-treated progesterone control mice which was restored significantly in Fattolin 200 and $400 \mathrm{mg} / \mathrm{kg}$ treated mice.

\section{DISCUSSION}

Obesity is considered as one of the major health threats and is a disorder of civilization. The appropriate changes in the style of living and pharmacotherapy can be considered for effective management. ${ }^{29}$ Obesity is a multifactorial disorder with a strong link being already established between imbalance of hormones and development of obesity. ${ }^{3,4}$

Progesterone is a steroidal female sex hormone playing an important role in menstrual cycle and pregnancy. ${ }^{7}$ Progesterone impairs fat metabolism and induces obesity due to fat accumulation. ${ }^{11,12}$ Progesterone induced obesity is a well-known model for screening the anti-obesity effect of drugs. Polyherbal formulations are considered as one of the safe and effective treatment for management of numerous lifestyle disorders and disease. ${ }^{30}$ Hence the present study was undertaken to investigate the effect of Fattolin, a polyherbal formulation in progesterone induced obesity model. 


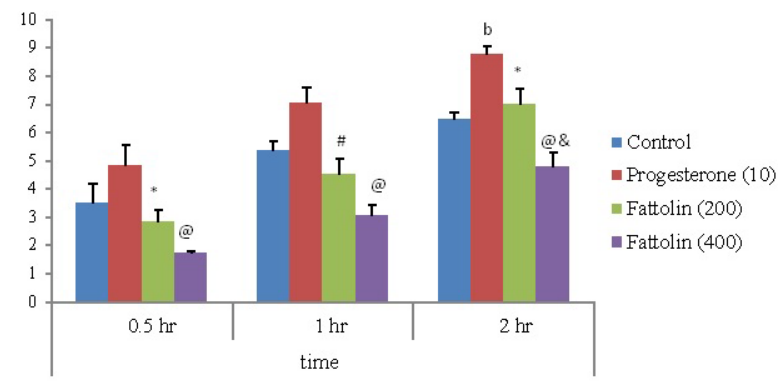

$\mathrm{n}=6$, One way ANOVA followed by Tukey's test.

${ }^{\mathrm{t}} \mathrm{P}<0.01$ Vs Control; ; $\mathrm{P}<0.05,{ }^{\mathrm{P}} \mathrm{P}<0.01$, ${ }^{\mathrm{E}} \mathrm{P}<0.001$ Vs Progesterone; ${ }^{\circledR} \mathrm{P}<0.01$ Vs Fattolin 200

Figure 1: Effect of four weeks treatment of Fattolin on food intake.

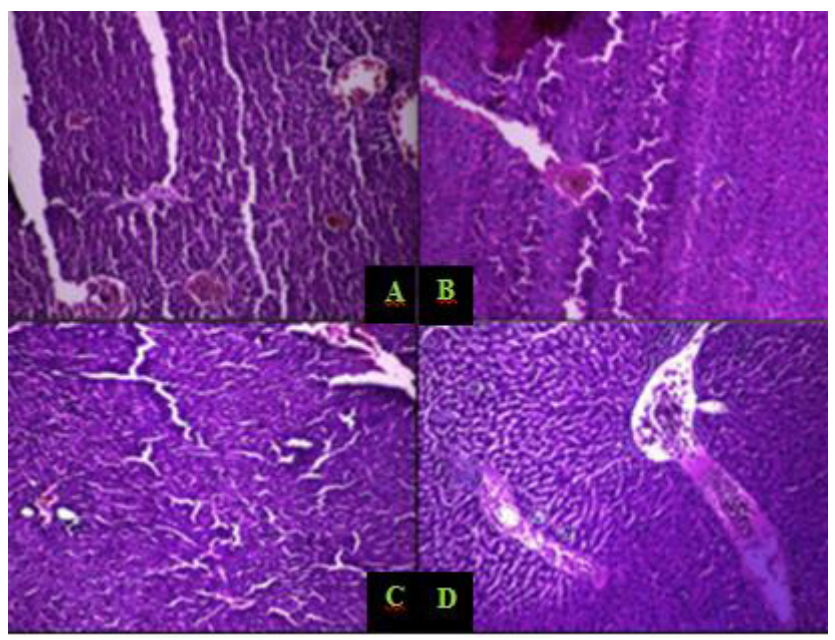

Figure 2: Histological section of liver stained with H \& E- 100 $X[A]$ Control mice [B] Progesterone showed mild congestion and minor focal necrosis in hepatocyte. However, [C] Fattolin $(200 \mathrm{mg} / \mathrm{kg})$ [D] Fattolin $(400 \mathrm{mg} / \mathrm{kg})$ restored the hepatic architecture.

Progesterone administration is associated with increase in food intake and body weight. In the present study, subcutaneous administration of progesterone produced significant increase in food intake and thereby body weight in agreement with previous reports. ${ }^{31}$ We have observed significantly decreased food intake and body weight in mice treated with Fattolin at dose level of 200 $\mathrm{mg} / \mathrm{kg}$ and $400 \mathrm{mg} / \mathrm{kg}$. The effect of Fattolin on food intake is mainly due to its active principles which have been reported for various therapeutic effects like hypo lipidaemia, thermo genesis and carminative. ${ }^{16-19}$ An increase in liver weight suggests hypertrophy or hyperplasia. ${ }^{32}$ Progesterone has been reported as the steroid hormone that promotes synthesis and storage of fats. As liver is highly metabolising organ, prone to deposition of fat, the present investigation suggested significantly increased liver weight on progesterone administration. ${ }^{23}$ Fattolin treated mice produced significant decrease in the liver weight. However, it failed to produce any remarkable change in the relative liver weight.

Progesterone is seen to influence the measures of habituation including ambulation, grooming and rearing. ${ }^{33}$ This effect of progesterone was may be due to increased body weight which results in lethargy, leading to decreased motility. ${ }^{34}$ Progesterone administration for 28 days in female mice significantly decreased the number of ambulation and rearing while increased grooming as evident from open field test. Fattolin administration at both dose levels produced significant increase in the number of ambulation and rearing while decrease in grooming. This effect is mainly due to decrease in body weight and thereafter its effect on motility in Fattolin treatment.

The impairment in fat and carbohydrate metabolism is reflected in the biochemical parameters like blood glucose and lipid profile associated with progesterone administration. It is reported that increased progesterone level in pregnant women may suffer from gestational diabetes due to hyperphagia. Thus in our study progesterone treated group showed significant rise in the blood glucose level which completely reversed by the effect of Fattolin $200 \mathrm{mg} / \mathrm{kg}$ and $400 \mathrm{mg} / \mathrm{kg}$ treatment. ${ }^{6,25}$ Progesterone modulated various biochemical parameters in female mice by stimulation of lipoprotein lipase which is responsible for hydrolysis of dietary fat leading to enhancement of fat storage in body, leading to a significant increase in serum lipid profile. ${ }^{35}$ Progesterone produced an increase in blood glucose levels, and other parameters of lipid profile viz. TG, TC, LDL and VLDL while decrease in levels of HDL. Fattolin treated mice showed a significant decrease in TG, TC, LDL and VLDL. Oral administration of Fattolin at both doses produced a significant increase in levels of HDL. The present study indicated an increase level of liver enzymes viz. SGOT and SGPT with progesterone administration. An increase in the levels of these enzymes is an indication of hepatic injury or abnormality. ${ }^{36} 28$ day treatment with Fattolin $(200 \mathrm{mg} / \mathrm{kg}$ and $400 \mathrm{mg} / \mathrm{kg}$ ) significantly reduced the levels of SGOT and SGPT when compared to progesterone non treated group. All the results indicated a significant difference in the Fattolin $400 \mathrm{mg} / \mathrm{kg}$ treated mice when compared to Fattolin $200 \mathrm{mg} / \mathrm{kg}$, thus suggesting maximum anti-obesity action at higher dose.

The histopathological examination reveals the probable toxic effect of the drug on vital organs. ${ }^{37}$ The section of liver in progesterone treatmed group indicated distorted structures of functional unit as mild congestion and focal necrosis of hepatocytes. However, the hepatic 
architecture was restored with Fattolin $(200 \mathrm{mg} / \mathrm{kg}$ and $400 \mathrm{mg} / \mathrm{kg}$ ) treatment.

In conclusion, 28 days of oral administration of polyherbal formulation, Fattolin restored body weight, exploratory behaviour as well as biochemical and histopathological alterations due to the various constituents. Maximum activity was observed at dose of $400 \mathrm{mg} / \mathrm{kg}$. Thus, it can be considered as an effective treatment in management of obesity owing to its potential anti-obesity effect.

\section{ACKNOWLEDGEMENT}

The authors would like to acknowledge Prof. M. N. Nawale, President, Sinhgad Technical Education Society, and Dr. K. N. Gujar, Principal, Sinhgad College of Pharmacy, Vadgaon, Pune, India, for providing necessary facilities.

\section{CONFLICT OF INTEREST}

The authors declare that they have no competing interest.

\section{REFERENCES}

1. Kopelman P. Obesity as a medical problem. Nature. 2002;404(6778):635-43.

2. Roh $C$ and Jung $U$. Screening of crude plant extracts with anti-obesity activity. Int J Mol Sci. 2012,13(2):1710-9.

3. Björntorp P. The regulation of adipose tissue distribution in humans. Int $\mathrm{J}$ Obes Relat Metab Disord. 1996;20(4):291-302.

4. Klok M, Jakobsdottir $S$ and Drent $M$. The role of leptin and ghrelin in the regulation of food intake and body weight in humans: A review. Obes Rev. 2007;8(1):21-34.

5. Lovejoy J. The Influence of Sex Hormones on Obesity across the Female Life Span. Journal of Women's Health. 1998;7(10):1247-56.

6. Boonyaratanakornkit V, Pateetin P. The Role of Ovarian Sex Steroids in Metabolic Homeostasis, Obesity, and Postmenopausal Breast Cancer: Molecular Mechanisms and Therapeutic Implications. Bio Med Res. 2015;1:1-13.

7. Carlson M, Thiel K, Yang S, Kimberly and. Leslie K. Catch It Before It Kills: Progesterone, Obesity, and the Prevention of Endometrial Cancer. Discov Med. 2012;14(76):215-22.

8. Graham J and Clarke C. Physiological Action of Progesterone in Target Tissues. Endocrine Rev. 1997;18(4):502-19.

9. Amy $\mathrm{J}$ and Tripathi V. Contraception for women: an evidence based overview. BMJ. 2009;339:b2895.

10. Trussell J. Contraceptive failure in the United States. Contraception. 2011;83(5):397-404.

11. Mandour T, Kissebah A and Wynn V. Mechanism of oestrogen and progesterone effects on lipid and carbohydrate metabolism: alteration in the insulin: glucagon molar ratio and hepatic enzyme activity. Eur J Clin Invest. 1977;7(3):181-7.

12. Amatayakul $K$, Sivasomboon $B$ and Thanangkul $O$. A study of the mechanism of weight gain in medroxyprogesterone acetate users. Contraception. 1980;22(6):605-22.
13. loannides-Demos L, Proietto $\mathrm{J}$ and McNeil J. Pharmacotherapy for obesity. Drugs. 2005;65(10):1391-418.

14. Manning S, Pucci A and Finer N. Pharmacotherapy for obesity: novel agents and paradigms. Therapeutic Advances in Chronic Disease. 2014;5(3):135-48.

15. Peter A. The Role of Plant-Derived Drugs and Herbal Medicines in Healthcare. Drugs 1997;54(6):801-40.

16. Tanabe M, Chen Y, Saito K, Kano Y. Cholesterol biosynthesis inhibitor component from Zinziber officinale Rosc. Chem Pharm Bull. 1993;41(4):710-3.

17. Srinivasan K. Black pepper and its pungent principle-piperine. A review of diverse physiological effects. Crit Rev Food Sci Nutr. 2007;47:735-48.

18. Sharma N and Kaushik P. Medicinal, Biological and Pharmacological Aspects of Plumbagozeylanica(Linn.). J Pharmacog and Phytochem. 2014;3(4):117-20.

19. Anurekha J and Gupta V. Chemistry and pharmacological profile of guggulA review. Indian J Trad Knowledge. 2006;5(4):478-83.

20. Jain D, Bavage P, Thanekar G and Gokhale M. Acute and Subacute Oral Toxicity Studies of Fattolin Polyherbal Formulation in Laboratory Rats. Inventi Rapid: Planta Activa. 2015(3):1-7.

21. Gundamaraju R and Mulaplli S. Evaluation of Anti-Obesity Activity of Lantana camara Var Linn. by Progesterone Induced Obesity on Albino Mice. IJPPR. 2013;4(4):213-8.

22. Kaur $G$ and Kulkarni S. Differential Effect Of A Polyherbal Formulation Ob-200g In Male And Female Mice Subjected To Forced Swim Stress. Indian J Physiol Pharmacol. 2000;44(3):281-9.

23. Chidrawar V, Patel K, Shiromwar S and Kshirsagar A. Exploiting anti-obesity mechanism of Clerodendrumphlomidis against two different models of rodents, Int J Green Pharm. 2014;5(3):216-28.

24. Trinder P. Determination of glucose in blood using glucose oxidase with an alternative oxygen acceptor. Ann Clin Biochem1. 969;6:24-8.

25. Henry R.J.U.M. Clinical Chemistry, $2^{\text {nd }}$ ed. Harper and Row Publishers, New York; 1974.p. 1440-3.

26. Laurell S. A Method for Routine Determination of Plasma Triglycerides. Scandinavian J Clin Lab Invest1. 966;18(6):668-72.

27. Thomas L. Clinical Laboratory Diagnostics. $1^{\text {st }}$ ed. TH-Books Verlagsgesellschaft, Frankfurt;1998;652-6.

28. Friedewald W, Levy $\mathrm{R}$ and Fredrickson D. Estimation of the concentration of low density lipoprotein cholesterol in plasma, without use of preparative ultracentrifuge. Clin Chem. 1972;18(6):499-502.

29. Wadden T, Berkowitz R, Womble L, Sarwer D ,Phelan S, Cato R, Hesson L, Osei S, Kaplan R ,Stunkard A. Randomized Trial of Lifestyle Modification and Pharmacotherapy for Obesity. N Eng J Med. 2005;353(20):2111-20.

30. Pal S, Shukla Y. Herbal Medicine: Current Status and the Future. Asian Pacific J Cancer Prev. 2003;4:281-8.

31. Schwartz $S$ and Wade G. Effects of estradiol and progesterone on food intake, body weight, and carcass adiposity in weanling rats. Am J Physiol. 1981;240(5):499-503

32. Sellers R, Morton D, Michael B and Roome N. Society of Toxicologic Pathology Position Paper: Organ Weight Recommendations for Toxicology Studies. Tox Pathol. 2007;35(5):751-5.

33. Gyermek L. Some effects of progesterone and related steroids on the central nervous system. Int J Neuropharm. 1967;6(3):191-8.

34. Bjursell M, Gerdin A, Lelliott $C$ and Egecioglu E. Acutely reduced locomotor activity is a major contributor to Western diet-induced obesity in mice. Am J Physiol Endocrinol Metab. 2008;294(2):E251-60.

35. Shirling $\mathrm{D}$, Ashby $\mathrm{J}$ and Baird J. Effect of progesterone on lipid metabolism in the intact rat. J Endocrinol. 1981;90(2):285-94.

36. Giannini E, Testa R and SavarinoV. Liver enzyme alteration: a guide for clinicians. CMAJ. 2005;172(3):367-79.

37. Crissman J, Goodman D and Hilderbrandt P. Best practices guideline: toxicologic histopathology. Tox Pathol. 2004;32:126-31. 